\title{
THE PROCESS OF INFORMAL SPATIAL PLANNING: A LITERATURE OVERVIEW
}

\author{
Ankit MISHRA \\ Riga Technical University, Riga, Latvia \\ Corresponding author e-mail: ankit.civil.official@gmail.com
}

\begin{abstract}
For years now, spatial planners have played a vital role in managing and balancing the different interests of a wide range of stakeholders in a specific region. With the help of formal and informal instruments, the design of spatial plans is created, but sometimes there are either flaws or gaps in the plans by which the stakeholders would have benefitted. It is important to witness the changes being made in the pattern of planning and analyse the suggestions being made by the intellectual involved. In this article, existing scientific literature has been reviewed, as well as dynamic and comparative analysis and synthesis techniques have mainly been employed for the study. The aim of this article is to study the spatial planning practices in Europe and analyse the governance in spatial planning, which as a result shows different planning modes. With the help of literature, formulating the characteristics of informal planning is an eccentric part of this analysis to understand the direction of development in formal institutions. Test planning process is analysed using the ten characteristics of informal formal planning. From the best practice perspective, decision making in spatial planning must be decentralised, and the tools of spatial planning must be less binding, which has been broadly practiced in Switzerland. The outcome of the research will help avoid floccinaucinihilipilification in spatial planning.
\end{abstract}

Keywords: Formal and informal planning tools, institutions, planning system and practices, spatial planning.

\section{INTRODUCTION}

Spatial planning first originated in the $6^{\text {th }}$ European Conference of Ministers responsible for Regional Planning (CEMAT) in 1983. In 1983, the concept of spatial planning was defined in two points, which were points 8 and 9 to be precise. The concept was defined as follows: 8. "Regional/spatial planning gives geographical expression to the economic, social, cultural and ecological policies of society; 9. It is at the same time a scientific discipline, an administrative technique and a policy developed as an interdisciplinary and comprehensive approach directed towards balanced regional development and the physical organisation of space according to an overall strategy". The characteristics of regional/spatial planning, which were defined in the conference, were democratic, comprehensive, functional and long-term oriented (Prospects of development and of spatial planning in maritime regions, 1983).

The description of spatial planning for almost three decades has been revolving around the same characteristics, which are participation or inclusion (democratic), co-ordinated (comprehensive), caring about shared values or cultures, etc. 
(functional), sustainable (long-term oriented). There have been new additions and changes made in past decades to the approaches of Spatial Planning to maintain the characteristics initiated at the conference of 1983.

Therefore, in this article, the spatial planning of European countries is analysed to understand its governance and approach. An independent and parallel informal planning process must be introduced to aid the formal planning process, such as test planning process.

The review of scientific literature, as well as co-relation analysis of informal planning and comparative analysis of governance style in spatial planning have been used in this study. It is vital to understand the characteristics of the informal planning process in the literature to have a clear understanding of the path for developing an informal planning process in the future. In this article, test planning process, which is an informal planning process, is analysed and compared to the characteristics of informal planning.

\section{SPATIAL PLANNING}

In recent decades, an ideal spatial planning system always reinvents itself to tackle different types of situations like radical changes in politics, economy, technologies etc. (Friedmann, 2005). Innovation is the key in institutional settings of spatial planning to continuously allow spatial planning practices to adapt according to the circumstances (Reimer, 2014). Innovation in spatial planning can be derived as advancements of technological instruments, such as GIS (Geographic Information System) (Blaschke, 2010), collaboration of formal and informal institutions for common goal, adaptability of formal and informal institutions for project-based development. "The task of the planning enterprise is to critically interrogate the governance practices that currently exist and to help governance communities concerned with place qualities to develop different approaches where these are seen to be failing. This involves attention to both discourses and practices; to what already exists, what is emerging and what might possibly emerge in a specific context" (Healey, 2003).

It is also important to understand the requirement of different places and it is vital that the governance of planning has strategic approaches towards "governance of place" (Healey, 2003). The authors (Loepfe \& Eisinger, 2017) of Assemblages for Urban Transformation propose spatial planning to move beyond usual practices; they elaborate "in order to transform the existing urban fabric, we think that new spatial conceptions beyond traditional ideas and visualizations that are based on robust processes are necessary. Robustness in this context means the contents of plan worlds are adaptable over time and are at the same time shared by a broad range of different stakeholders." Adaptability of spatial planning institutions also refers to the flexibility, which results in continuity and changes from traditional methods (top to down) to bottom-up. This non-traditional approach ("top" refers to national and "bottom" refers to lower/municipal institutions) gives more power to the local authorities and room for independent project-based approach. But, what if just the informal tools initiated the spatial planning process or project-based development were targeted at complex projects? To understand the core of recent 
traditions of spatial planning, the next section shows the governance style, approach and traditions of European countries in spatial planning. Information regarding European Countries and their governance, approach and previous family in spatial planning is shown in Table 1.

Table 1. European Countries and their Governance, Approach and Previous Family in Spatial Planning (developed by the author)

\begin{tabular}{|c|c|c|c|}
\hline Countries & $\begin{array}{l}\text { Previous } \\
\text { Family }\end{array}$ & Approach & $\begin{array}{c}\text { Governance in Spatial } \\
\text { Planning }\end{array}$ \\
\hline Denmark & Scandinavian & Comprehensivelintegrated & $\begin{array}{l}\text { Independent municipal plans } \\
\text { (No Vision at regional, } \\
\text { national levels). This led to } \\
\text { power struggles between } \\
\text { private and public institutions } \\
\text { (Damsgaard, 2014) }\end{array}$ \\
\hline Finland & Scandinavian & $\begin{array}{c}\text { Comprehensivelintegrated } \\
\text { (based on land-use } \\
\text { planning) }\end{array}$ & $\begin{array}{l}\text { Binding regulations at the } \\
\text { regional level, with binding } \\
\text { and independent development } \\
\text { of plans at the municipal } \\
\text { level. (Land-use guidelines at } \\
\text { the national level) (Sari \& } \\
\text { Mäntysalo, 2014) }\end{array}$ \\
\hline Netherlands & Napoleonic & $\begin{array}{l}\text { Comprehensivelintegrated } \\
\text { (moving towards an } \\
\text { economic development } \\
\text { approach) }\end{array}$ & $\begin{array}{l}\text { No vision/plan illustrated at } \\
\text { the national level. } \\
\text { Municipalities can interpret } \\
\text { national plans and policies. } \\
\text { (No Hierarchy) (Zonneveld \& } \\
\text { Evers, 2014) }\end{array}$ \\
\hline Germany & Germanic & $\begin{array}{l}\text { Comprehensivelintegrated } \\
\text { and regional-economic }\end{array}$ & $\begin{array}{l}\text { National plans must be } \\
\text { approved by lower planning } \\
\text { levels (regional, municipal). } \\
\text { Highly flexible planning } \\
\text { system helps in practicing } \\
\text { informal planning system } \\
\text { (Blotevogel et al., 2014) }\end{array}$ \\
\hline France & Napoleonic & $\begin{array}{l}\text { Regional-economic } \\
\text { (moving towards } \\
\text { comprehensive/integrated) }\end{array}$ & $\begin{array}{l}\text { Under the national sectoral } \\
\text { guidelines, regional } \\
\text { guidelines are regularly } \\
\text { updated. Independent and } \\
\text { collaborated development at } \\
\text { the local/municipal level } \\
\text { (Geppert, 2014) }\end{array}$ \\
\hline Italy & Napoleonic & Urbanism & $\begin{array}{l}\text { Complex legislative } \\
\text { framework (national level) } \\
\text { and low room for innovation } \\
\text { as a master plan dominates at } \\
\text { the local/municipal level } \\
\text { (Lingua \& Servillo, 2014) }\end{array}$ \\
\hline Greece & Napoleonic & Urbanism & $\begin{array}{l}\text { Top-to-down planning } \\
\text { system (traditional planning } \\
\text { system) but has flexibility } \\
\text { towards } \\
\text { development (Getimis, 2014) }\end{array}$ \\
\hline
\end{tabular}




\begin{tabular}{|c|c|c|c|}
\hline $\begin{array}{l}\text { Flanders\North } \\
\text { ern Belgium }\end{array}$ & Napoleonic & Land-use management & $\begin{array}{l}\text { Belgium is divided into three } \\
\text { planning regions (Flanders, } \\
\text { Wallonia, Brussels) with no } \\
\text { national plans. Low room for } \\
\text { innovation at local and } \\
\text { regional levels because of } \\
\text { strategised structural plans } \\
\text { (Broeck et al., 2014) }\end{array}$ \\
\hline $\begin{array}{l}\text { United } \\
\text { Kingdom }\end{array}$ & British & Land-use management & $\begin{array}{l}\text { Union state system of } \\
\text { Northern Ireland, Scotland, } \\
\text { Wales and England, where } \\
\text { the national government } \\
\text { supervises strategically by } \\
\text { planning law, policies and } \\
\text { guidelines. There is direct } \\
\text { control by the national } \\
\text { government over major } \\
\text { projects. Local authorities } \\
\text { have the freedom to regulate } \\
\text { development and policies } \\
\text { (Nadin \& Stead, 2014) }\end{array}$ \\
\hline $\begin{array}{l}\text { Czech } \\
\text { Republic }\end{array}$ & East Europe & $\begin{array}{l}\text { Mixed use of all four } \\
\text { approaches }\end{array}$ & $\begin{array}{l}\text { Czech Republic has a three- } \\
\text { level planning system } \\
\text { (national, regional and } \\
\text { municipal), where public } \\
\text { interests are also taken into } \\
\text { account, but lesser emphasis } \\
\text { is given to nature, cultural } \\
\text { heritage, water and mineral } \\
\text { resources (Maier, 2014) }\end{array}$ \\
\hline Turkey & $\begin{array}{l}\text { (South) East } \\
\text { European }\end{array}$ & Urbanism & $\begin{array}{l}\text { The planning system has } \\
\text { always been centrally } \\
\text { controlled and driven } \\
\text { (traditional, top-down). There } \\
\text { are no binding documents at } \\
\text { the regional level for planning } \\
\text { at local levels. Clash of } \\
\text { interests, bureaucracy delays } \\
\text { and no cooperation within } \\
\text { authorities (Erkut \& Sezgin, } \\
\text { 2014) }\end{array}$ \\
\hline Poland & $\begin{array}{l}\text { (Central) East } \\
\text { Europe }\end{array}$ & Comprehensivelintegrated & $\begin{array}{l}\text { Traditional planning system } \\
\text { with national strategies } \\
\text { impacting the adjustment of } \\
\text { regional and local plans } \\
\text { (Cotella, 2014) }\end{array}$ \\
\hline
\end{tabular}

In order to understand the priorities of each approach, it is important to understand the four traditions defined by the Commission of the European Communities (CEC) in 1997:

- Comprehensive/integrated: "This tradition is managed by a framework (national to local), which is coordinated by highly responsive institutions and this mature tradition requires proper commitments from political and 
planning departments" (CEC, 1997). Damsgaard (2014) writes that Denmark uses this tradition and the municipalities are responsible for preparing local plans. However, there are some flaws in Danish spatial planning practices as there have been power struggles between private organisations and the Danish government in recent years;

- Regional-economic: "In this tradition, the national government plays a vital role in spatial planning and the funds for public infrastructure, which will help in regaining the objectives of the social economy" (CEC, 1997). Geppert (2014) explains that in France the spatial planning practices have become more vertical, horizontal cooperative and e coherent because France has evolved into a comprehensivelintegrated system from a regionaleconomic one;

- Urbanism: "This tradition gives more emphasis on urban design, architecture, townscape and building control" (CEC, 1997). Greece is one of the users of this tradition. Getimis et al. (2014) explain that this tradition is also a "regulatory" spatial planning system, which is dominated by hierarchical structures, strong legislative binding, command, and control. But, just by the example of Greece, we can understand that project-based development, public involvement, and informal plans can be practiced under this tradition;

- Land-use management: "In this tradition, the planning is more closely associated with the narrower task of controlling the change of use of land at the strategic and local levels" (CEC, 1997). The United Kingdom is one of the users of this tradition, and Nadin \& Stead (2014) explain the power struggle between private organisations and local people after the localisation process of the United Kingdom during 2010. Therefore, the authors stress that the United Kingdom is still on a track of economic and business development rather than giving priority to local people's interests.

Hence, there is a need in every spatial planning approach for an unbiased way of planning, which delivers the interest of stakeholders and this new approach can help spatial planners balance the interests in spatial planning.

To overcome the complex or non-complex situations in spatial planning, a parallel method must be introduced, which gives an equal opportunity to diverse stakeholders transparently and democratically. A parallel method that facilitates the formal process can be introduced by the help of the informal planning method. To have a closer look at informal planning, literature is analysed to build the characteristics of informal planning in spatial planning.

\section{INFORMAL SPATIAL PLANNING}

It is essential to analyse the literature, which describes informal planning, and to understand the role of tools and stakeholders, who influence spatial planning. The outcome of this analysis will help formulate the characteristics of informal spatial planning:

- Informal planning process or methods should not replace the existing spatial planning practice of that region, but informal planning should "facilitate 
formal process" of spatial planning (Reimer et al., 2014; Blotevogel et al., 2014; Briassoulis, 1997; Leibenath et al., 2016; McFarlane et al., 2012; Needham, 2005; Scholl, 2017);

- Informal planning adds "flexibility" in the spatial planning process, which allows the planners to focus on a specific problem (Reimer et al., 2014; Getimis \& Giannakourou, 2014; Getimis et al., 2014; Newman \& Thornley, 1996; Mäntysalo et al., 2015);

- Informal spatial planning can help in achieving matured results with the help of "discourses" (Reimer et al., 2014; Getimis \& Giannakourou, 2014; North, n.d.; Certomà, 2017; Sartorio, 2005; Syssner \& Meijer, 2017; Papamichail \& Perić, 2017; Carmona, 2017; Leibenath et al., 2016; Roy, 2009);

- Informal planning could also be an "ad hoc" system that is used whenever needed (Blotevogel et al., 2014; Getimis \& Giannakourou, 2014; Briassoulis, 1997; Reimer, 2013; Assche et al., 2012);

- Informal spatial planning requires a degree of "innovation" to continuously face the challenges of planning (Reimer et al., 2014; Getimis et al., 2014; Roy, 2009; Certomà, 2017; Scholl, 2017);

- Informal planning method is a "non-traditional method" of spatial planning, which is not influenced by hierarchy culture of planning (Reimer et al., 2014; Damsgaard, 2014; Briassoulis, 1997; Donovan, 2008; Certomà, 2017; Kušar, 2010; Syssner \& Meijer, 2017; Carmona, 2017);

- Informal spatial planning process is a multi-planning level "cooperated" process, which allows the actors to have an equal say in decision making (Blotevogel et al., 2014; Evers, 2013; Högström et al., 2017; Kušar, 2010; Healey, 1999; Scholl, 2017; Lutzoni, 2016);

- Informal planning "requires governance" to avoid potential conflict and progress towards a legitimate solution (Blotevogel et al., 2014; Donovan, 2008; Mäntysalo et al., 2015; Syssner \& Meijer, 2017; Healey, 1999; Evers, 2013);

- Informal planning requires "inclusion" of different stakeholders for unbiased results or planning direction (Getimis \& Giannakourou, 2014; Sartorio, 2005; Papamichail \& Perić, 2017; Carmona, 2017; Hanssen \& Falleth, 2014; Mäntysalo et al., 2015; Kušar, 2010);

- "Transparency" in informal spatial planning is vital as it keeps the stakeholders of different levels well informed as well as makes the planning process conflict less (Lemke, 2000; Mäntysalo et al., 2015).

Therefore, the characteristics of informal planning can be formulated in 10 points that are as follows:

1. Facilitates formal process;

2. Flexible;

3. Matured by discourses;

4. Ad hoc;

5. Innovative;

6. Non-traditional;

7. Cooperated at all planning levels; 
8. Requires governance;

9. Inclusive;

10. Transparent.

The characteristics of informal planning shows that informal planning can facilitate the spatial planning process especially in countries that are still using a top-down way of planning, this, on the other hand, can help in avoiding floccinaucinihilipilification in spatial planning.

\section{Informal Planning Practice: Test Planning Process}

Test planning process/method is derived by B. Scholl et al. (2013) as the problem-solving method in complex planning situations. The authors further elaborate the seven factors involved in the test planning process, which are as follows (Scholl et al., 2013):

- Concurrence of ideas: To get better results, all of the ideas are explored, but the most efficient one goes through;

- Rhythm: Repeated discussions lead to the maturity of ideas and solutions;

- No winner: There are no winners or losers in this process. Only better ideas help resolve complex situations;

- Ad hoc organisation: Independent process, which involves locals and officials so that the process is completely impartial;

- Communication: More locals and various actors are invited to be involved in the test planning process. Therefore, the marketing of all the steps to attract public interest is important;

- Finding problems and solutions: Test planning process is a dynamic process; hence, redefining and identifying new possibilities of problems allow being prepared;

- Protected process: Keeping the whole process protected with the help of closed meetings to have better ideas and solutions.

Loepfe and Eisinger in 2017 defined the test planning process as a conventional planning process that has "transdisciplinary modes of exploring, testing and selecting of new development paths, building of new alliances through political opinionmaking and consensus-building, and enabling bottom-up procedures and establishing project-oriented conventions".

Test planning process has been used in several projects internationally. However, the process was used only in complex planning/developing projects. In the city of Patras (Greece), the test planning process was used for a project related to railway and transportation to have resilient governance in the spatial development of Greece (Papamichail \& Perić, 2017). The process was successful. However, the question lies whether an ad hoc process is enough or a parallel informal process, which supplements the spatial planning process for better results, is required? Having a parallel process would require spatial planning tools to be less binding.

\section{DISCUSSION}

What makes Swiss spatial planning different from other European countries? The answer is the "decentralized way of decision-making and informal planning 
procedures when tackling complex spatial problems" (Peric \& Hoch, 2017). This is the reason why informal planning process can be practiced and developed in Switzerland. Test planning process is still a developing method that has only been used thrice in Switzerland, Greece, and Serbia. There are some similarities and dissimilarities between Informal Planning characteristics and the characteristics of the Test Planning Process. Therefore, a co-relation between them would help in finding the direction for future development and improvement of informal planning processes. Co-relation of the characteristics of informal planning identified in this article and the existing test planning process (Scholl et al., 2013) is shown in Table 2.

Table 2. Co-relation of the Characteristics of Informal Planning and the Existing Test Planning Process (developed by the author)

\begin{tabular}{|l|l|l|l|l|l|l|l|l|l|l|}
\hline $\begin{array}{c}\text { Characteristics } \\
\text { of Informal } \\
\text { Planning } \\
\text { Characte } \\
\text { ristics } \\
\text { of Test Plan- } \\
\text { ning Process }\end{array}$ & 1. & 2. & 3. & 4. & 5. & 6. & 7. & 8. & 9. & 10. \\
\hline $\begin{array}{l}\text { Concurrence of } \\
\text { ideas }\end{array}$ & & & $\mathrm{X}$ & & & & & & & \\
\hline Rhythm & & & $\mathrm{X}$ & & & & & & & \\
\hline
\end{tabular}

The ten characteristics of informal planning developed in this article are corelated with test planning process in the table above. The denotations of numbers 
are as follows: 1 - Facilitates formal process; 2 - Flexible; 3 - Matured by discourses; 4 - Ad hoc; 5 - Innovative; 6 - Non-traditional; 7 - Cooperated at all planning levels; 8 - Requires governance; 9 - Inclusive, and 10 - Transparent.

Only directly related characteristics of the test planning process and the characteristics of informal planning formulated in this article are marked as " $\mathrm{X}$ " in the Table 2. Concurrence of ideas is directly related to the characteristic of matured by discourses because both relate to obtaining results after exploring the ideas. Rhythm is defined as the repeated discussion for matured results. Thus, matured by discourses was the right match. No winner of test planning process matches with the characteristic "requires governance" as governance will help in maintaining a balance of interests. The characteristics "inclusive" and "ad hoc" was matched with an ad hoc organisation because of the independent nature of both characteristics and the inclusion of different stakeholders. Communication was defined as the involvement and inclusion with the help of marketing etc.; hence, there is the match with the characteristic "inclusive". An innovative way of getting matured results explains the match between finding problems and solution with the characteristics "matured by discourses" and "Innovative". Characteristics "transparent" and "requires governance" was matched with the protected process because the test planning process was transparent during the closed process among the stakeholders, which required governance to be maintained.

The test planning process is a great method, which has been developed but it still needs to expand its value adding factors, such as easier ways to interact with common stakeholders, which will add higher maturity in results.

The test planning process is flexible as it has been used in three different countries with different planning traditions, and it also facilitates the formal process and is a non-traditional method. Hence, the characteristics of the test planning process must be updated in future literature.

The test planning process is also a method developed to be used in complex projects; therefore, it lacks the essence of a collaborative approach in all spatial planning developments.

\section{CONCLUSION}

In spatial planning, decision making should be decentralised, and the tools of spatial planning must be less binding.

Informal planning procedures such as test planning process can be used in tackling complex spatial problems. A revised version of the test planning process must be introduced, which can work independently and can aid all spatial planning activities.

The characteristics of informal planning analysed clearly indicate that informal planning can aid the spatial planning process especially in countries that are still using a traditional way of planning (top-down) and this will help in avoiding floccinaucinihilipilification in spatial planning.

The test planning process shows that it can work in a different spatial planning framework, which makes it flexible to be used in complex projects of different European countries. 


\section{REFERENCES}

Blaschke, T. (2010). Object based image analysis for remote sensing. ISPRS Journal of Photogrammetry and Remote Sensing, 65(1), 2-16. https://doi.org/10.1016/j.isprsjprs.2009.06.004

Blotevogel, H. H., Danielzyk, R. and Münter, A. (2014). Spatial Planning in Germany: Institutional inertia and new challenges. Edited: Mario Reimer, et al. Spatial Planning Systems and Practices in Europe: A Comparative Perspective on Continuity and Changes. Routledge.

Briassoulis, H. (1997). How the others plan: exploring the shape and forms of informal planning. Journal of Planning Education and Research, 17, 105-117. https://doi.org/10.1177/0739456X9701700202

Broeck, P.V.d., Moulaert, F., Kuhk, A., Lievois, E., and Schreurs, J. (2014). Spatial Planning in Flanders Serving a bypassed capitalism? Edited: Mario Reimer, et al. Spatial Planning Systems and Practices in Europe: A Comparative Perspective on Continuity and Changes. Routledge.

Carmona, M. (2017). The formal and informal tools of design governance. Journal of Urban Design, 22(1), 1-36. https://doi.org/10.1080/13574809.2016.1234338

Certomà, C., Notteboom B. (2017). Informal planning in a transactive governmentality: Re-reading planning practices through Ghent's community gardens. Planning Theory, 16(1), 51-73. https://doi.org/10.1177/1473095215598177

Cotella, G. (2014). Spatial Planning in Poland Between European Influence and Dominant Market Forces Edited: Mario Reimer, et al. Spatial Planning Systems and Practices in Europe: A Comparative Perspective on Continuity and Changes. Routledge.

Council of Europe. (1983). $6^{\text {th }}$ European Conference of Ministers responsible for Regional Planning, CEMAT, In Prospects of development and of spatial planning in maritime region. Torremolinos, Spain: 19-20 May.

Damsgaard, O. (2014). The Danish Planning System 1990-2010: Continuity and decay. Edited: Mario Reimer, et al. Spatial Planning Systems and Practices in Europe: A Comparative Perspective on Continuity and Changes. Routledge.

Donovan, M.G. (2008). Informal cities and the contestation of public space: The case of Bogotá's street vendors, 1988-2003. Urban Studies, 45(1), 29-51.

Erkut, G. and Sezgin, E. (2014). Spatial and Strategic Planning in Turkey: Institutional change and new challenges. Edited: Mario Reimer, et al. Spatial Planning Systems and Practices in Europe: A Comparative Perspective on Continuity and Changes. Routledge.

Evers, D. (2015). Formal institutional change and informal institutional persistence: the case of Dutch provinces implementing the Spatial Planning Act. Environment and Planning C: Government and Policy, 33(2), 428-444. https://doi.org/10.1068/c1391

Friedmann, J. (2005). Planning Cultures in Transition. Bishwapriya Sanyal eds. Comparative Planning Cultures. Routledge.

Geppert, A. (2014). France, Drifting Away from the "Regional Economic" Approach. Edited: Mario Reimer, et al. Spatial Planning Systems and Practices in Europe: A Comparative Perspective on Continuity and Changes. Routledge.

Getimis, P. and Giannakourou, G. (2014). The Evolution of Spatial Planning in Greece after the 1990s: Drivers, directions and agents of change. Edited: Mario Reimer, et al. Spatial Planning Systems and Practices in Europe: A Comparative Perspective on Continuity and Changes. Routledge.

Hanssen, G. S., \& Falleth, E. I. (2014). Market-Oriented Urban Planning - Constraining Citizen Participation. Local Government Studies, 40(3), 403-428. https://doi.org/10.1080/03003930.2013.834254

Healey, P. (1999). Institutionalist Analysis, Communicative Planning, and Shaping Places. Journal of Planning Education and Research, 19(2), 111-121. https://doi.org/10.1177/0739456X9901900201

Högström, J., Balfors, B., \& Hammer, M. (2017). Planning for sustainability in expansive metropolitan regions: exploring practices and planners' expectations in Stockholm, Sweden. European Planning Studies, 26(3), 439-457. https://doi.org/10.1080/09654313.2017.1391751 
Kušar, S. (2010). Landscape studies informal planning practices: Some evidence from Slovenia. Journal of Landscape Studies, 3(3), 159-165.

Leibenath, M., Wirth, P., \& Lintz, G. (2016). Just a talking shop? - Informal participatory spatial planning for implementing state wind energy targets in Germany. Utilities Policy, 41, 206-213. https://doi.org/10.1016/j.jup.2016.02.008

Lemke, T. (2000) Foucault, governmentality, and critique. Paper presented at the Rethinking Marxism Conference, University of Amherst, Amherst, MA, 21-24 September.

Lingua, V. and Servillo, L. (2014). The Modernization of The Italian Planning System. Edited: Mario Reimer, et al. Spatial Planning Systems and Practices in Europe: A Comparative Perspective on Continuity and Changes. Routledge.

Loepfe, M., \& Eisinger, A. (2017). Assemblages for Urban Transformation. disP - The Planning Review, 53(1), 20-31. https://doi.org/10.1080/02513625.2017.1316526

Lutzoni, L. (2016). In-formalised urban space design. Rethinking the relationship between formal and informal. City Territ Archit, 3(20). https://doi.org/10.1186/s40410-016-0046-9

Maier, K. (2014). Changing Planning in The Czech Republic. Edited: Mario Reimer, et al. Spatial Planning Systems and Practices in Europe: A Comparative Perspective on Continuity and Changes. Routledge.

Mäntysalo, R., Jarenko, K., Nilsson, K. L. \& Saglie, I-L. (2015). Legitimacy of Informal Strategic Urban Planning Observations from Finland, Sweden and Norway. European Planning Studies, 23(2), 349-366. https://doi.org/10.1080/09654313.2013.861808

McFarlane, C. \& Waibel, M. (eds.). (2012). Urban Informalities: Reflections on the Formal and Informal. London: Ashgate.

Nadin, V. and Stead, D. (2014). Spatial Planning in The United Kingdom, 1990-2013. Edited: Mario Reimer, et al. Spatial Planning Systems and Practices in Europe: A Comparative Perspective on Continuity and Changes. Routledge.

Needham, B. (2005). The New Dutch spatial planning act: Continuity and change in the way in which the Dutch regulate the practice of spatial planning. Planning Practice and Research, 20(3), 327-340. https://doi.org/10.1080/02697450600568662

Newman, P. and Thornley, A. (1996). The National Framework: Planning Systems. In Urban Planning in Europe: International Competition, National Systems and Planning Projects, pp. 27-75.

North, D. C. (1990). An introduction to institutions and institutional change. In Institutions, Institutional Change and Economic Performance, Cambridge University Press, 3-10. https://doi.org/10.1017/CBO9780511808678.003

Papamichail, T. and Perić, A (2017). Informal Planning: Towards Promoting Resilient Governance in Greece. International conference on Smart and Sustainable Planning for Cities and Regions, SSPCR 2017, 523-536. https://doi.org/10.1007/978-3-319-75774-2_35

Peric, A. \& Hoch, C. (2017). Spatial planning across European planning systems and social models: A look through the lens of planning cultures of Switzerland, Greece and Serbia. Proceedings: AESOP 2017 Conference "Spaces of Dialog for Places of Dignity: Fostering the European Dimension of Planning”. https://doi.org/10.3929/ethz-b-000226627

Reimer, M. (2013). Planning Cultures in Transition: Sustainability Management and Institutional Change in Spatial Planning. Sustainability, 5(11), 4653-4673. https://doi.org/10.3390/su5114653

Roy, A. (2009). Strangely Familiar: Planning and the Worlds of Insurgence and Informality. Planning Theory, 8(1), 7-11. https://doi.org/10.1177/1473095208099294

Sari, H.K. and Mäntysalo, R. (2014). The Recent Development of The Finnish Planning System The city of Vantaa as an executor, fighter and independent actor. Edited: Mario Reimer, et al. Spatial Planning Systems and Practices in Europe: A Comparative Perspective on Continuity and Changes. Routledge.

Sartorio, F. S. (2005). Strategic Spatial Planning A Historical Review of Approaches, its Recent Revival, and an Overview of the State of The Art in Italy. disP - The Planning Review, 41(162). https://doi.org/10.1080/02513625.2005.10556930 
Scholl, B. (2017). Building Actor Relationships and Alliances for Complex Problem Solving in Spatial Planning: The Test Planning Method. disP - The Planning Review, 53(1), 46-56. https://doi.org/10.1080/02513625.2017.1316544

Scholl, B., Vinzens, M. and Staub, B. (2013). Test Planning - A Method with a Future: Main features and information on the practical application of the test planning process using Riedholz/Luterbach as an example.

Syssner, J, Meijer, M. (2017). Informal Planning in Depopulating Rural Areas: A resource-based view on informal planning practices. European Countryside, 9(3), 458-472. https://doi.org/10.1515/euco-2017-0027

Van Assche, K., Beunen, R., \& Duineveld, M. (2012). Formal/Informal Dialectics and the SelfTransformation of Spatial Planning Systems. Administration \& Society, 46(6), 654-683. https://doi.org/10.1177/0095399712469194

Zonneveld, W. and Evers, D. (2014). Dutch National Spatial Planning at The End of An Era. Edited: Mario Reimer, et al. Spatial Planning Systems and Practices in Europe: A Comparative Perspective on Continuity and Changes. Routledge.

\section{AUTHOR' SHORT BIOGRAPHY}

Ankit Mishra is a second-year Ph. D. student of Management Science and Economics at Riga Technical University. He has previously completed his Master's studies at Riga Technical University within the programme "Civil Construction and Real Estate Management". Ankit has pursued his Bachelor of Technology in Civil Engineering and also has relative work experience as a Civil Engineer. He has diverse technical abilities, management knowledge, and social science researching skills. His research interests are related to spatial planning, real estate market, and sustainable development. 